\title{
ROLE OF KNOWLEDGE MANAGEMENT IN SPORT ORGANIZATIONS
}

Gjorgji Manev", Institute for Sociological, Political and Juridical Research, Ss Cyril and Methodius University, Skoplje

Jorde Jakimovski, Institute for Sociological, Political and Juridical Research, Ss Cyril and Methodius University, Skoplje

\begin{abstract}
The popularity of sport and recreation contributed to having sport facilities and sport grounds constructed throughout our whole country. It is in these facilities, fields and grounds where sport activists such as members of amateur sport clubs and professional sport clubs and sport organizations, put into practice their sport-related ideas. They have strong encouragement from their fans, political organizations, the spectators in the well-equipped sport facilities, on the Internet, in the information and communication technologies, from knowledge management and in the media. Knowledge management in successful sport organizations can be associated with their sustainability, continuity and achievement of long-lasting competitive results in sport. In the efforts to create additional values for sport organizations, a proposal was made to apply the processes of knowledge creation, codification, sharing and transfer of knowledge, as well as its utilization in the efforts to achieve sport goals.
\end{abstract}

Key words: Knowledge Management, Sport Management, Sport Organization

JEL Classification: Z29, D83

\section{ULOGA UPRAVLJANJA ZNANJEM U SPORTSKIM ORGANIZACIJAMA}

Sažetak: Popularnost sporta $i$ rekreacije doprinela je izgradnji sportskih objekata $i$ sportskih terena širom cele naše zemlje. U ovim objektima i na ovim terenima, sportski aktivisti, poput članova amaterskih $i$ profesionalnih sportskih klubova $i$ sportskih organizacija, sprovode svoje ideje u vezi sa sportom. Oni imaju punu podršku navijača,

\footnotetext{
*gjorgjimanev@yahoo.com
} 
političkih organizacija $i$ gledalaca u dobro opremljenim sportskim objektima, na Internetu, $u$ informaciono-komunikacionim tehnologijama, u procesu upravljanja znanjem i medijima. Upravljanje znanjem u uspešnim sportskim organizacijama može se povezati sa njihovom održivošću, kontinuitetom $i$ postizanjem dugotrajnih konkurentnih rezultata u sportu. U naporima da se poveća uspešnost sportskih organizacija, predloženo je da se primeni proces kreiranja znanja, kodifikacije, razmene i prenosa znanja, ali i upotreba znanja za postizanje sportskih ciljeva.

Ključne reči: upravljanje znanjem, menadžment u sportu, sportske organizacije

\section{INTRODUCTION}

Development of sport in the Republic of Macedonia dates as early as since establishment of the first sport clubs on the Balkan. With the purpose of achieving this, in the very beginning, friendly matches and sport events were organized. Then, in 1919, the first official football match was held between the domestic junior football team and the football team of the officers of the English army (Shegavikj, 2016). On an international level, sport events were organized as early as in ancient times. As per historic records, the first Olympic Games were held in 776 BC in the place of Olympiad in Greece (Masterman, 2009) and this event is associated with the religious festival honoring God Zeus. The Olympic Games are an event that is still being held. Here ultimate results are achieved and recently tribute was paid to the most successful Olympic Games participant ever, Michael Phelps, for his total of 23 Olympic Games gold medals.

Inspiration for practicing sport arose mainly from the wish to compete in some sports, which gradually spread throughout Europe and globally, aiming at promotion of healthy lifestyle, keeping body fit, creating conditions for wider cooperation both on domestic and on international level, as well as turning the world into a decent place for living. Since the early beginnings, many generations of sportspeople have come, and many sport facilities have been constructed, ensuring proper conditions for competition among these sportspeople. Over and over again medals have been won and sport events have been organized. Sport-related knowledge is increasingly being used, both with a view to achieving ultimate results, and also for ordinary recreational needs related to people's endeavors to keep fit. New sport facilities are constantly being constructed and the old ones are being renovated and improved, with the current motto of the Olympic Games in Rio de Janeiro, Brazil, "Together we can change the world.", meaning, by means of sport we can make the world a 
better place for living. This approach is confirmed with the intention to let all these sport facilities available for the public as well.

Achievement of ultimate professional sport results, having in mind the severe competitiveness of the other countries and their clubs, implies excellent preparedness, utilization of the most recent advanced sport-related knowledge in the respective competing sport event, support from knowledge management when identifying and selecting the sportspeople and monitoring their development, as well as backing for the very organizing of the sport events where ultimate results are achieved. Fulfillment of these goals necessitates preparedness, resilience, professional approach, competitive culture, application of knowledge management in all the activities and processes, which would ensure sustainability of the sport clubs and organizations.

Despite the fact that the Republic of Macedonia is not a huge country with enormous population from where greater number of promising and gifted sportspeople could be recruited, the Republic of Macedonia still does achieve results which match its capacities, the country's investment in certain sport events, and the interest of the public for the sport event in question. Pursuant to the above and the country's sport strategy, there are domestic championships in football, handball, basketball, volleyball and other individual sport events organized. Some of the sport clubs and national teams successfully compete on international level. This refers to handball in particular.

\section{BASIC CHARACTERISTICS OF SPORT ORGANIZATIONS}

Sport clubs in our country could be generally grouped into amateur clubs, professional clubs and teams and national teams. Professional teams, in addition to participating in domestic championships, also successfully compete in their regional leagues and European team championships. National teams also regularly take part in the qualification matches for European and World Championships, organize or participate in preparatory friendly matches, and some of these teams have recently more frequently been seen in the final matches at European championships. As well as the above, in the Republic of Macedonia there are also a number of active sport organizations, including the Olympic Games Committee.

Typical for amateur sport clubs is that the driving force in these clubs is mere enthusiasm; it is these clubs where future talents and top-class sportspeople are detected and recruited. Their training commences as early as in elementary school, which is the reason why the Government of the Republic of Macedonia, through its Agency for Youth and Sport, drew up and implemented the project for construction of 35 new sport halls, 50 auxiliary playgrounds, 100 tennis 
courts, 100 multi-purpose playgrounds throughout the country, and one artificial rock for climbing. All these sport facilities are aimed at improving the conditions for doing sport for students, young sportspeople and sport lovers, as well as for support of amateur sport activities, where emphasis is put on light training sessions and temporary contracts with the sportspeople.

Regarding amateur sport, club founders are of crucial significance. Recently we have been hearing of clubs owners, and therefore efforts are made to define ownership of clubs in compliance with the Law on Sport and the Law on Peoples' Associations and Foundations. Here we should also mention all the concerned parties and shareholders such as the club supporters, fans, former sportspeople praiseworthy for the growth and the success of the club. And last but not least, we must not leave out the small regional clubs, local businessmen and municipality officials.

Apart from amateur sport clubs, there are also professional sports clubs (which include the national teams) which differ from the former ones by the fact that the latter's sportspeople receive predefined income, are insured and are entitled to bonuses depending on the outcome. They are bound with guaranteed contracts which shall be duly and timely fulfilled. These clubs receive appreciable incomes coming from their sport activities, and accordingly, they can afford recruiting and contracting top-quality sportspeople in their clubs. Concerning current trends on international level, quite illustrative and explanatory is the case of the English football championship and their clubs (Walters \& Hamil, 2010), where there are investments in the sport clubs.

Sport organizations are designed to put into practice a sophisticated manner of organizing sport. They are invariably accompanied by investors and sponsors. One of their distinguishing features is the perfect level of organization of their supporters and fans. Their leadership is well-structured and the members of their Managing Board are carefully selected. They are actively present in the media and in that way had gained their support and interest. They are normally very successful in collecting their incomes which are generated from admission fees, advertising sponsorship, incomes gained from media rights and other types of incomes. In the highly developed West European countries, state sport organizations also own sport facilities.

Sport organizations are additionally capable of successfully putting into practice organizational theories (Slack \& Parent, 2006) which are tailored according to the organizations' needs. These organizations are very well aware of the fact that their existence depends on their opponents (competitive parties) as much as on themselves, since they are all fighting for a better position in the championship. For that reason, sophisticated knowledge and excellent 
knowledge management is a must, as well as the organization Management who, in turn, make very good use of knowledge management (Hislop, 2013), all that for the sake of preparation, coordination and cooperation with the competitive sport organizations.

All the sport activities, their organizing and the competitiveness are directed towards the sport event (Byers, Parent \& Slack, 2012), i.e. matches with accurately predefined times of happening. Additionally, there are sport events related to leagues, regional, European and world championships. Taking into consideration the fact that there are qualification matches preceding entering these championships, the latter are fairly dynamic and their participants change on an annual basis, depending on the results achieved in the domestic championships. Consequently, sport organizations basically acquire their revenues in the season when the placing which guarantees entering the league had been achieved, and in the following season when the championship would take place. For the sport organizations this is a double profit, i.e. revenues from domestic championship and from international matches.

Nowadays we can identify one more complex model of sport organizing at an international level. Historically, this model of organizing switched from the traditional geographical-hierarchical approach to a network model of organizing. It has also been aided by the sophisticated support of the information-communication technologies (Travica, 1998), application of knowledge management (Ashouri, Boroumand \& Darzi, 2015) and utilization of modern means of transportation. As a result, conditions were created to involve a wider range of shareholders, such as the sport organizations themselves, sponsors, satellite and land transmission systems, state and European institutions, local organizers of sport events, manufacturers of sport paraphernalia, a variety of agencies and smaller clubs.

A sport organization can be composed of sport clubs and their men's and women's teams, players, leagues, championships and a Managing Board that supervises and directs the operation of the sport organization. There are also players' associations which ensure that the players' rights shall be observed. Because of the previously explained complexity of sport and the existence of diverse entities in a society with which sport organizations cooperate (this especially covers the business organizations concerned and the political environment), there is a strong need of interaction, cooperation in the competition process and mutual harmonization. This also applies to application of the accepted norms and values, which can be extremely important when allocating the sport resources, sharing the profit, carrying out the management 
processes and knowledge management, as well as when directing the sport organization.

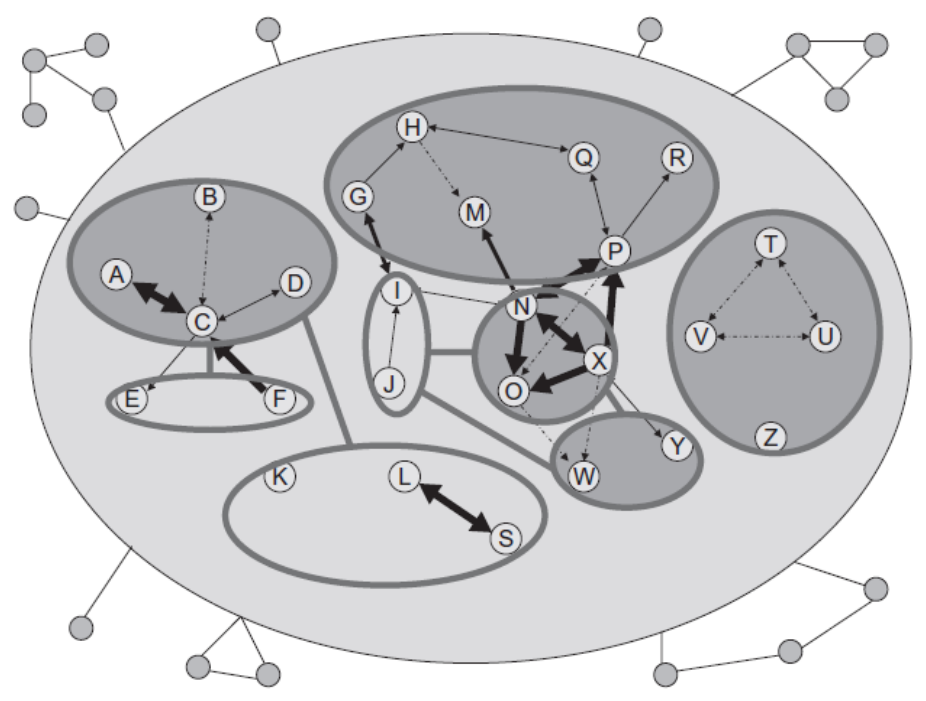

Figure 1 Illustration of an inter-organizational network

Note. Retrieved from „Network Perspectives on Organizations“, from Quatman and Chelladurai, 2007, International Perspectives on the Management of Sport, 61-80.

Successful implementation of the stipulated strategy in sport and accomplishment of the interests of the society involves cooperation between the sport organizations and the government institutions. Namely, it is commonly the case when the government policies directly affect the determination of specific sport targets. In addition to that, the government investments in sport facilities are all but negligible, as well as the government direct support of the sportspeople in their efforts to achieve their sport goals.

\section{SPORT AND PREDICTIONS REGARDING ITS DEVELOPMENT SEEN THROUGH THE PRISM OF KNOWLEDGE MANAGEMENT}

One of the crucial issues and dilemmas in sport is how to ensure its sustainability and development, how to attract the more possible spectators and how to ensure organization of sport championships. As for the public, what matters to them is duly provision of sufficient pieces of data, information and 
knowledge (Peterson, Ahamed \& Erdogan, 2010) related to recreational facilities, attending sport events and taking advantage of sport activities. Knowledge management can be useful and represents an asset in all the activities related to sport and sport organizations.

Sports, doing sport and recreational activities (Maguire, 2014) are of crucial significance for a person's keeping fit and being healthy and in a good mood. Professional sport contributes to development of competitive spirit among sport lovers, which indirectly implies understanding the complexity of living nowadays, which means living with and accepting the differences existing in our current environment. Sport and sport events can also contribute to one's getting familiar with one's closer of wider surroundings; sport is good grounds for cooperation, and can also serve as a basis for transfer of ideas. On domestic level, professional sport resulted into getting two (2) gold, five (5) silver and six (6) bronze Olympic medals, as well as one European championship in club handball for women.

In its mission, sport is strongly encouraged by its supporters and fans, political organizations, well equipped sport facilities, the Internet, informationcommunication technologies, knowledge management (McInerney \& Koenig, 2011) and the media (Nicholson, 2007). In the efforts to create a successful sport organization, it is very important that its Management and owners pay particular attention to a few things. One of them is proper managing of the sport organization (where application of the management functions is a must) $(\mathrm{Li}$, MacIntosh \& Bravo, 2012; Robinson, 2010), marketing (Mason, 1999; Kase, Urrutia de Hoyos, Sanchis \& Bretón, 2007; Garland, Charbonneau \& Macpherson, 2008), and in particular management with human resources (Chelladurai, 2006) and sport talents.

Sport devotees, in particular those keen on sport events, are very important for sport clubs and sport organizations. They are source and basis of future strategies of the clubs. It is commonplace for them to be members of the sport organization, financially support it, and in some western highly developed countries they are owners of sport clubs. What matters to them most is to be timely and duly informed of the activities of the club. News and information of this type can be transferred using the media, the Internet, television and social networks (Walker, 2016). Monitoring of these activities can be conducted through a number of indicators, such as: whether the sport event is in due time announced, to which scope and how it is done, whether the contents of the information promotes the club and the competition itself, whether there is data on the players, and the like. As far as the spectators are concerned, they value 
the possibilities of purchasing a ticket, the access to the sport facilities, the means of transportation and the accommodation capacities.

All these requirements can nowadays be easily and successfully met by using information-communication technology and the Internet provided by the telecommunication operators. In addition to that, there are also software application programs which are an indispensible asset when performing the operational processes of the sport organization. These application programs are used for popularization of sport, for theoretical training available everywhere by using the Internet, for sharing information and sport news among the clubs, for sales of tickets for sport events, for arrangements related to means of transportation and for provision of accommodation capacities. Thus, all the sport enthusiasts and sport lovers have a wide variety of choices to pick and choose from. For real accomplishment of that goal nowadays there is a possibility to use web-based portals and financial means of payment.

If sport clubs wish to build up a successful sport organization, they need to attract the more spectators possible, to popularize their sport club, to increase their incomes coming from commercials, to provide for sponsorship, to profit from the television broadcast of their performance in the matches, and in order to achieve it all, they are in grave need of support from the media, the marketing and the banking sector. The media can be television stations, radio, Internet portals, printed media and telecommunication operators. They all can ensure sustainable services. This will enable the respective sport organization to be in a favorable position by being able to profit from its activities, at the same time communicating intensively with its devotees and supporters. 


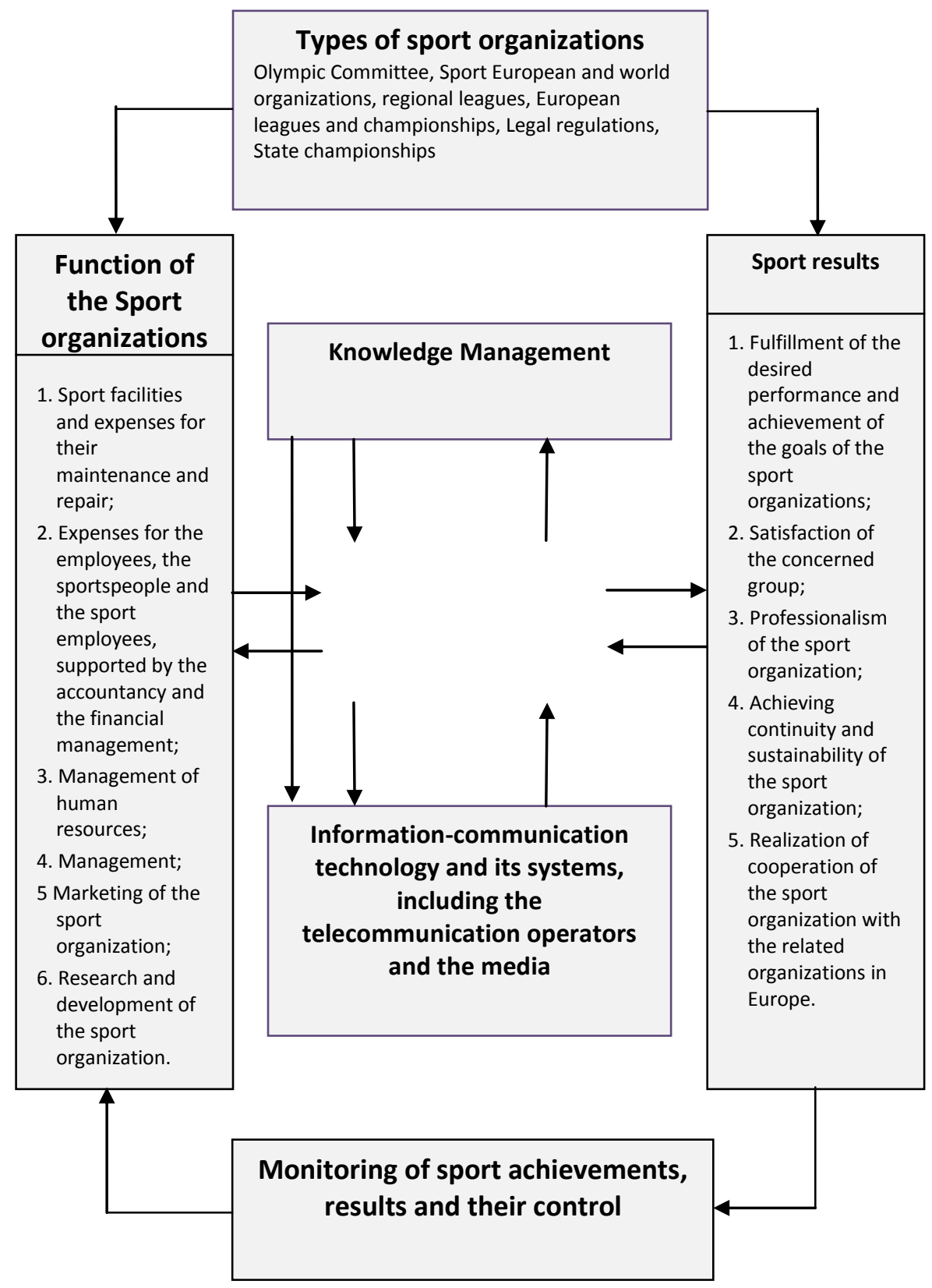

Figure 2 Relationship between knowledge management and sport activities 
Fulfillment of these goals is impossible without provision of good quality sport facilities, needed both for the very sport event and for the preliminary preparatory training sessions of the sportspeople. These sport facilities could be classified into many groups depending on the quality of the sport ground/court, the distance of the spectators from the playing ground, the view on the playing ground and how comfortable the seats are, the access to the sport facility, inside security of the spectators, heating of the sport facilities (in case of sport halls), accommodation of the teams, the equipment used for informing the spectators and the sportspeople, and the sport devices and technological gadgets used during the match. Modern sport facilities are supposed to be fitted with security devices monitoring the entrances of the sport facility, to have sport shops as well as refreshment areas that can be used by the spectators before, during and after the sport event. Furthermore, modern sport facilities are fitted with separate training halls and fitness gyms, as well as separate rooms for the media.

In order to be able to realize all these sport activities, a sport organization needs successful management (Hoye, Smith, Nicholson \& Stewart, 2015). Good management is supposed to ensure proper organization and coordination of a majority of activities, people, rules, intentions and continuity. It is management that is in charge of allocating the needed resources and knowledge about sport activities; the management is expected to motivate the sports employees, to manage to define short-term objectives, and to develop a culture of cooperation when realizing these objectives. The Management is also responsible for functioning of the sport organization. It is directly involved in marketing the sport event at the sport market. Its role is to supervise planning, coordination and control of the sport organization.

The role of marketing (Smith \& Stewart, 2015) is to succeed in getting familiar with the behavior of all the parties and shareholders of the sport organization. A particular attention needs to be paid to appropriately promoting and selling each and every sport event, which is far from an easy task. It has to be achieved at desirable prices. Concerning the promotion of the sport event, commonly used are the interested media present there. Realization of these activities is a task that has to be assigned to individuals fully capable of successfully completing that task.

The function of the human resources management is to achieve the desired mutual relations within the organization. It is also successfully practiced for recruiting and selecting new staff and for realization of the activities of the sport organization. In a sport organization, human resources management is particularly focused on identifying desirable sportspeople for certain positions 
in the club. It is also responsible for assigning concrete tasks and responsibilities required by the sport club, which are related to realization of the club strategy in the respective competing year. In other words, human resources management deals with monitoring and development of the human resources and their upgrading depending on and in compliance with the stipulated organizational performances. Apart from that, it directly monitors the sportspeople's devotion, their discipline and sport lifestyle, as well the cooperation among the players.

\section{SUSTAINABILITY OF THE SPORT ORGANIZATIONS}

The role of knowledge management in the successful sport organizations could be related to reaching their sustainability, continuity and achieving long-term competitive advantage in sport. This implies taking permanently care of the operation of the organization, making decisions on issues associated with the organizational processes, as well as development of gifted sportspeople and sports employees. Sport organizations also need to be actively defined, which would allow their shaping the future. The same could be done by initialization and exercising influence on its activities. What is also needed is a systematic approach towards the sport organization, as well as towards its surrounding, which, in turn, necessitates existence of good-quality and permanent mutual communication.

Achievement of these goals is determined by the influence arising from topclass sport achievements on a wider geographical scale, which implies existence of perfectly prepared, ambitious and well-trained sportspeople, sport clubs and sport organizations. The gain from carrying out such activities can result into successful operation and reaching the desired goals which match the stipulated ones.

Examples of processes going on in top sport are presented in table 1. The information provided covers the most famous teams in top sport events in Europe and in the United States of America. The table presents and explains the achievements of the famous sport teams according to criteria such as the majority-based ownership of the team, its value depending on the multi-year achievements, and the revenues coming from various sources. There is also data about the coaches' and players' earnings, and the available capacity of the sport facilities. When drawing up this analysis, data was presented of the attendance of the sport fans and spectators at the matches for some of the teams at European football championships, where the average attendance in the season 2013-2014 was $88.48 \%$, which is definitely an excellent attendance that can meet the needs and goals of the top sport clubs. Hence the outstanding average 
earning of the top football players, amounting $\$ 37.68$ million, i.e. the average earnings per player amounting $\$ 7.74$ million. Regarding European football coaches, the best-paid ones make $\$ 11$ million.

This type of achievements are feasible when there is development of such sport operations that are connected with sport management functions, all that with regard to achieving the defined values, processes and priorities of the organization. This, in particular, refers to the management-related activities, to the marketing of the sport organization, its operability, and the role that development and usage of modern information-communication technology plays in its operations. Here we should also mention the financial operations and the benefits from sport-related researches, which will allow the sport organization to determine and direct its actions and development, and that will basically mean ensuring future existence.

When applying a variety of organizational aspects in the operation of the sport organizations and clubs, a number of factors are to be taken into consideration, since they could affect the organization's operations and success. Some of these factors are: the economic environment that affects the organization's surroundings, the social environment and the club's sustainability capacities, something which is in direct correlation with the degree of the fans' and spectators' interest in the respective sport. Other influential factors are: the political support offered by the authorities in charge, the legal regulations that are supposed to spur sport organizing, as well as the very sport competitive events on a regional and European level. Additionally, attention must be paid to all the activities of the sport organization that can be controlled. 
Table 1

The Most Valuable Teams of Top Sports

\begin{tabular}{|c|c|c|c|c|c|c|c|c|c|c|c|c|c|}
\hline \multicolumn{2}{|l|}{$\begin{array}{l}\text { (in } 000000 \\
\text { of USA \$) }\end{array}$} & & & & & \multicolumn{4}{|c|}{ Valuation Breackdown } & \multirow[b]{2}{*}{$\begin{array}{c}\text { Dept } \\
\text { Value } \\
(\%) \\
\end{array}$} & \multirow[b]{2}{*}{$\begin{array}{c}\text { Player } \\
\text { Annual } \\
\text { Expenses }\end{array}$} & \multirow[b]{2}{*}{$\begin{array}{c}\text { Coach } \\
\text { Annual } \\
\text { Selary } \\
\end{array}$} & \multirow[b]{2}{*}{ Capacity } \\
\hline $\begin{array}{l}\text { Team } \\
\text { Name }\end{array}$ & $\begin{array}{l}\text { League } \\
\text { (Country) }\end{array}$ & $\begin{array}{c}\text { Majority } \\
\text { Shareholders }\end{array}$ & $\begin{array}{c}\text { Champi } \\
\text { onships } \\
\text { (No). }\end{array}$ & $\begin{array}{l}\text { Team } \\
\text { Value } \\
\text { (Year) }\end{array}$ & $\begin{array}{c}\text { Revenue } \\
\text { (Operatin } \\
\text { Income) }\end{array}$ & Sport & Market & Stadium & Brand & & & & \\
\hline $\begin{array}{l}\text { Dallas } \\
\text { Cowboys }\end{array}$ & $\begin{array}{l}\text { NFL } \\
\text { (USA) }\end{array}$ & $\begin{array}{l}\text { Jerry } \\
\text { Jones }\end{array}$ & 5 & $\begin{array}{l}4000 \\
\text { (Sep. } \\
2015)\end{array}$ & $\begin{array}{l}620 \\
(270)\end{array}$ & 1535 & 1046 & 1022 & 497 & 5 & 148 & 5 & 100000 \\
\hline $\begin{array}{l}\text { New } \\
\text { England } \\
\text { Patriots }\end{array}$ & $\begin{array}{l}\text { NFL } \\
\text { (USA) }\end{array}$ & $\begin{array}{l}\text { Robert } \\
\text { Kraft }\end{array}$ & 4 & $\begin{array}{l}3200 \\
\text { (Sep. } \\
2015) \\
\end{array}$ & $\begin{array}{l}494 \\
(195)\end{array}$ & 1517 & 686 & 639 & 465 & 7 & 160 & 7,5 & 68756 \\
\hline $\begin{array}{l}\text { New York } \\
\text { Ranger }\end{array}$ & $\begin{array}{l}\text { NHL } \\
\text { (USA) }\end{array}$ & $\begin{array}{l}\text { Medison } \\
\text { Square } \\
\text { Garden }\end{array}$ & 4 & $\begin{array}{l}1200 \\
\text { (Nov. } \\
2015) \\
\end{array}$ & $\begin{array}{l}229 \\
(83,1))\end{array}$ & 119 & 568 & 358 & 163 & 0 & 80 & 2 & 18006 \\
\hline $\begin{array}{l}\text { Montreal } \\
\text { Canadiens }\end{array}$ & $\begin{array}{l}\text { NHL } \\
\text { (USA) }\end{array}$ & $\begin{array}{l}\text { Molson } \\
\text { Family }\end{array}$ & 24 & $\begin{array}{l}1175 \\
\text { (Nov. } \\
2015) \\
\end{array}$ & $\begin{array}{l}219 \\
(91,3)\end{array}$ & 121 & 580 & 297 & 180 & 20 & 72 & 2 & 21273 \\
\hline $\begin{array}{l}\text { New York } \\
\text { Knicks }\end{array}$ & $\begin{array}{l}\mathrm{NBA} \\
\text { (USA) }\end{array}$ & $\begin{array}{l}\text { Medison } \\
\text { Square } \\
\text { Garden }\end{array}$ & 2 & $\begin{array}{l}3000 \\
\text { (Jan. 2015) }\end{array}$ & $\begin{array}{l}307 \\
(108,9)\end{array}$ & 240 & 1456 & 907 & 447 & 0 & 88 & 5 & 19033 \\
\hline $\begin{array}{l}\text { Los Angeles } \\
\text { Lakers }\end{array}$ & $\begin{array}{l}\mathrm{NBA} \\
\text { (USA) }\end{array}$ & $\begin{array}{l}\text { Jerry Buss } \\
\text { Femily } \\
\text { Trust, } \\
\text { Philipe } \\
\text { Anschutz }\end{array}$ & 16 & $\begin{array}{l}2700 \\
\text { (Jan. 2016) }\end{array}$ & $\begin{array}{l}304 \\
(133,4)\end{array}$ & 38 & 1629 & 537 & 546 & 1 & 76 & 5 & 18997 \\
\hline $\begin{array}{l}\text { Real } \\
\text { Madrid }\end{array}$ & $\begin{array}{l}\text { La Liga } \\
\text { (Spain) }\end{array}$ & $\begin{array}{l}\text { Club } \\
\text { Members }\end{array}$ & 32 & $\begin{array}{l}3645^{(1)} \\
\text { (Apr. } \\
2016)\end{array}$ & $\begin{array}{l}694 \\
(162)\end{array}$ & 738 & 2386 & $323^{(2)}$ & 521 & 3 & $216^{(4)}$ & $10.5^{(4)}$ & 81000 \\
\hline Barcelona & $\begin{array}{l}\text { La Liga } \\
\text { (Spain) }\end{array}$ & $\begin{array}{l}\text { Club } \\
\text { Members }\end{array}$ & 24 & $\begin{array}{l}3703^{(1)} \\
\text { (Apr. } \\
2016)\end{array}$ & $\begin{array}{l}675 \\
(108)\end{array}$ & 666 & 2374 & $154^{(2)}$ & 509 & 2 & $202,1^{(4)}$ & $10,15^{(5)}$ & 98800 \\
\hline $\begin{array}{l}\text { Manchester } \\
\text { United }\end{array}$ & $\begin{array}{l}\text { BPL } \\
\text { (England) }\end{array}$ & $\begin{array}{l}\text { Glazer } \\
\text { Family }\end{array}$ & 20 & $\begin{array}{l}3687^{(1)} \\
\text { (Apr. } \\
2016)\end{array}$ & $\begin{array}{l}625 \\
(190)\end{array}$ & 655 & 2162 & $370^{(2)}$ & 500 & 20 & $200,6^{(4)}$ & $11,75^{(4)}$ & 76000 \\
\hline $\begin{array}{l}\text { Bayern } \\
\text { Munich }\end{array}$ & $\begin{array}{l}\text { Bundesliga } \\
\text { (Germany) }\end{array}$ & $\begin{array}{l}\text { Club } \\
\text { Members }\end{array}$ & 26 & $\begin{array}{l}3059^{(1)} \\
\text { (Apr. } \\
2016)\end{array}$ & $\begin{array}{l}570 \\
(60)\end{array}$ & 457 & 1796 & $381^{(2)}$ & 425 & 0 & $191,5^{(4)}$ & $24^{(4)}$ & 57300 \\
\hline Juventus & Serie $A$ & Agnelly & 32 & $1434^{(1)}$ & 390 & 186 & 954 & $135^{(2)}$ & 159 & 4 & $127,4^{(4)}$ & $5^{(5)}$ & 41000 \\
\hline
\end{tabular}

SCHOOL OF BUSINESS, 2/2017, 150 - 171 


\begin{tabular}{|l|l|l|l|l|l|l|l|l|l|l|l|}
\hline & $\begin{array}{l}\text { Tim } \\
\text { (Italy) }\end{array}$ & Family & & $\begin{array}{l}\text { (Apr. } \\
2016)\end{array}$ & $(81)$ & & & & & & \\
\hline $\begin{array}{l}\text { Paris Saint } \\
\text { Germain }\end{array}$ & $\begin{array}{l}\text { Ligue 1 } \\
\text { (France) }\end{array}$ & $\begin{array}{l}\text { Qatar Sport } \\
\text { Investment }\end{array}$ & 6 & $\begin{array}{l}578 \\
(1)\end{array}$ & 119 & 563 & $127^{(2)}$ & 132 & 0 \\
\hline
\end{tabular}

Source: Forbs, 2016.

USA, United State of America.

NFL, National Football League in the United State of America is a professional football league consisting of 32 teams.

NHL, National Hockey League in the United State of America is ice hockey league composed of 30 member clubs.

NBA, National Basketball Association in the USA has 30 teams.

BPL, Barclays Premier League, is English professional soccer league with 20 clubs.

(1) This value, with relation to the available source of data, is increased by the value of the stadium and the accompanying sport facilities and equipment.

${ }^{(2)}$ The data regarding the stadiums' values were obtained from the teams' portals or portals related to them.

(3) The value of the stadium of the French team Paris Saint Germain - "Parc de Princes" - was obtained from the investments into this stadium for EURO 2016 of 100 million Euros and its accounting value amounting 13 million Euros.

(4) Source: www.statista.com

${ }^{(5)}$ Source: www.totalsportek.com 
Ascertainment of clearly defined goals of the sport organization is of considerable significance for its survival on the sport market. These goals can be inter-connected and/or based on the desires and capacities for achievement of the results in question. The goals cannot be achieved without taking certain challenges and chances. The goals are to be measurable, clearly defined, easy to understand and long-lasting.

However, as the public has witnessed it many times, it is commonplace for some sport organizations to fail to realize their objectives due to the previously mentioned reasons, i.e. because of occurrence of imperfections in the process of realization of the organization's sport activities. It is these reasons that underlie the need to define special approaches for the sport clubs. Some of these approaches could be inclusion into the regional leagues, aiming at further expansion on the European sport market, mutual cooperation with other sport clubs, engagement of top professionals or development of their own competitive playing style which will be based on previously well trained and carefully selected players.

Implementation of the key goals can be achieved by participation in the annual championships. Such short-term objectives must be measurable both quantitatively and qualitatively, and they should be strived for continually and unyieldingly. This predominantly applies to the management, sport marketing activities, monitoring and development of human resources, realization of the stipulated dynamics of the sport club, knowledge management, application of the innovations in the informationcommunication technology and dedication to sport research, all that for the sake of keeping developing and being sustainable.

By realization of this sort of commitments, the sport organization will be able to define itself, become aware of the endeavors, achievements, goals and demands that it puts before its sportspeople, sport activists and sport employees. In that way it will successfully coordinate its goals, the needed performances and the appropriate remuneration within the sport organization. Thus an integrated sport organization will be created.

All this can be more easily accomplished provided there is a predetermined system of priorities for overpowering the identified problems, controlling activities for upgrading the timing dynamics, proper exploitation of the resources, clearly defined responsibilities, and commitment to development and considerations for overcoming the undesirable imperfections, as well as inspiring and enhancing enthusiasm and professional approach to work.

This ought to be supported by sport policies which, applying certain guidelines, rules and procedures, will ensure accomplishment of the preset short-term goals of the sport organization. In case things are not as 
mentioned above, then the sport organization will have to create its own system for reassessment of the existing policies. They should be grounded on measurable performances, based on which timely and suitable changes would be introduced where needed.

\section{WORKING SYSTEM AND MANAGEMENT WITHIN THE SPORT ORGANIZATION}

Working system in a sport organization is defined as a combination of one's practices, working structure and processes which maximize knowledge, skills, commitment, loyalty, flexibility and resilience of the subjects. Sport organizations encounter a majority of products, need to adapt to a larger global competitiveness, to manage the organization, to respond to the clients' requirements, to develop intellectual capital and to manage expenses.

Working system within a sport organization comprises a great number of interconnected parts which complement each other, with the purpose of accomplishing the goals of the sport organization. We talk about caring for the personnel, adaptation to the working environment and balancing the working processes. Sport organizations go beyond mere balancing, they create working environment which will produce most with the resources available, will meet the organization's needs and will create short-term and long-term goals of the organization. Managers, however, often use a system for tips and courses for quality. The decisions made by the Management in a sport organization, whether they refer to recruiting, transferring, promoting, developing or implementing people, are always in the context of long-term business practices in sport. A successful manager is supposed to possess the following traits: resourcefulness, determination, bravery, impartiality, selfreliance and honesty. A sport manager's activities are additionally affected by his/her aptitude to perform team work, being good at organizing things, communication with people and the promptitude in making decisions.

Marketing management in the working system of sport organizations is one of the most important and most complex activities, which ensures sensible, economic and efficient realization of the sport functions. Marketing in sport is frequently considered as a strategic choice made by the sport organizations in the field of creating material and financial wherewithal necessary for normal execution of the sport activities and realization of the set targets. On the one hand, sport marketing is an economic process of linking production (sport authorities with sportspeople and sport employees) with consumers (sport spectators and other kind of public), and on the other hand, it covers activities that make it possible to reach a reasonable state, i.e. transaction of ideas, goods and services for money. 
"The management of a sport organization predicts sport development, plans the activities related to sport, organizes the resources, processes and functions, contributes to development of human resources, ensures communication and coordination, decides on carrying out the best solutions, controls processes and eliminates conflicts." (Malicko, 2008).

Management of the working system in sport is a separate and scientific field which on the one hand means managing the sportspeople by their coaches, team experts and sport experts, and on the other hand it refers to efficient and effective management of sport organizations by sport management. Management in the working system of sport deals with financial wherewithal which is at disposal of the sport organizations, gives guidelines how to reach these funds, considers their structure and their allocation.

"Sport management means "a process of organizing and managing sport or sport organizations with a view to reaching sport objectives and other type of goals, in order to rationally use the resources available." (Bartoluci, 20013).

Put in other words, "Management gathers the resources - people, funds and equipment - needed to make operations and workers productive. Management creates tasks and organizes work which has to be realized. It ensures skills and coordination needed for the joint efforts, which are the essence of a sport organization. And last but not least, it directs and gives sense to things, which allows connecting a number of people into joint productive goals." (Covell et al 2002).

\section{KNOWLEDGE MANAGEMENT FOR SUCCESSFUL SPORT ORGANIZATIONS}

Sport organizations are fairly eager and impatient to produce information on their sport activities and events. This is so because sport and sport events happen continually on national and international level, and they are all covered nowadays by means of the modern video, telecommunication and information-communication technologies. Hence the constant need of application and inclusion of new knowledge into this field. That is the reason why knowledge management is extremely important for provision of permanent high quality sport-related services at reasonable and affordable prices, which is bound to result into sport's substantial contribution to the gross domestic product.

In the process of creation of added value to sport organizations, there are a few processes which belong to knowledge management. The first process is concerned with creation of knowledge (Ichijo \& Nonaka, 2006; Gustavson, 2007). One of the prerequisites for this process to happen is having previously collected the needed data on the respective sport organization and 
its surroundings. This data is additionally processed in order to obtain the information needed. Sources for this sport-related data are all sorts of reports on the respective sport organization, sport events which can be watched and obtained from the media, various sport researches conducted, correct reading and interpretation of the legal regulations related to sport, as well as the resources that can be provided from the Internet.

Further sharing of knowledge acquired in this manner, and its transfer to the places where it is needed, assumes this sharing of knowledge to be preceded by the process of its encryption. This covers creation of written sport cases and reports on some concrete sport event(s). The weaknesses and imperfections spotted and the lessons learnt from them, which can be used as guidelines for the future, can also be included in the reports.

Third thing to pay attention to is sharing the transfer of this stored knowledge (Leonard, 2006). Again, an imperative for this is existence of already created channels of communication which are additionally supported by the Internet, the mail systems, as well as by the personal smart phones and tablets which can also access the Internet.

The last process that is worth mentioning on this issue is related to exploitation of this knowledge for concrete purposes of the sport organization. This can take the sport organization to reaching the desired sport performances. They can also be found in a wide range of sport magazines, research reports, sport publications and books. As well as this way, they can also be gained and stored by experience. They can most commonly be found with well trained and experienced sportspeople, sport employees and managers. Generally speaking, they are available individually with the sportspeople.

Sport organizations should consider knowledge management as an advanced asset for reaching competitive sport advantages and results, doing that by using modern sophisticated organizational and information technology. It can also be successfully related to the sport facilities and grounds, and can be applied by means of the television media that are present nowadays in Europe and throughout the world. At the same time, the already described processes of knowledge management (sublimated in constant acquisition of sport knowledge, creation of new knowledge for sport-related needs and their integration) must be used exactly for achieving these sport goals.

Development of knowledge about sport and its organizations means well trained and competent sport employees. They can additionally upgrade themselves if there is a need of that. All this is with regard to increasing productivity in sport. But, how can it all be achieved? 
One of the possible approaches is making use of the Internet technologies which can now be successfully used as support for the sport processes, additionally aided by knowledge management. These technologies can be used for support of the individual sport knowledge, but also for the knowledge organization, which would actually mean uniting sport employees, technologies and organizing techniques applied in sport. Technologies used for support of knowledge management processes must be monitored by applicative programs of knowledge management, such as, for instance, monitoring of disputable moments at the matches, browsing data and contents, usage of the management application in sport organizations which allows managing the real estates of the sport organizations. Apart from the above, there are also applications used for process improvements in the sport organizations, support when teaching the sportspeople, and aid when transferring knowledge and development of the skills both of the sport employees and the sportspeople.

More advanced integrative approaches are establishment of virtual sport teams, which is pretty interesting for our national sport. They are designed for networking of the sport organizations which intend to compete on a European level. Knowledge management also values a lot the current researches in sport and the latest achievements with that respect.

Sport organizations can use knowledge management for making good quality sport decisions. This applies to cases of personal planning, as well as to cases of preparations for a championship. Knowledge management can be used to support the activities that concern everybody in the sport organization. It is frequently used as a direct asset to the sport processes, both in national and international championships, but especially when international competitions and championships are to be organized. Its systems for learning and sharing knowledge can be quite useful when analyzing various sport situations and sequences, particularly for the junior sportspeople.

Knowledge management can also be successfully used for preparing and facilitating sport organizing and its objectives, for improving its efficiency, for devising various strategies, all in all, activities that can take the sport organization to its predetermined competitive advantages.

\section{CONCLUSION}

In order to be able to achieve all goals stipulated, it is extremely important for the sportspeople to have an access to digital data and contents. Developing culture of mutual assistance and learning from each other is preferable. This particularly applies to cases when there are obvious unfavorable situations and imperfections, both in the very organization and 
in the sport grounds surroundings. Web portals and various types of databases with a diversity of information and knowledge can be used for realization of these commitments. This actually means creating grounds for the sport organization to be able to successfully face and overcome all the challenges it encounters.

Such efforts will allow the sport organizations and the clubs to create their own knowledge storehouse, i.e. they will save, store and use later where and needed the pre-acquired experiences and skills. At the same time, the sport organization will be prepared to successfully manage its estate and processes related to sport organizing and acting. Thus, all the sport shareholders will have their desired and enjoyable moments.

As well as this, these approaches are useful during the preparatory training of the sportspeople, during the regular performance of the sport processes (which are especially complex at international matches), for strengthening the capacities of the sport employees, and for design of the sport organizations, in compliance with the conditions applicable in sport. All together they can take the sport organization to better planning and organizing of its sport activities, increment in the revenues, appropriate usage of these revenues, profitable performance and, always very important, making sport fans, devotees and supporters pleased and satisfied.

With such an approach, the sport organization will be able to successfully develop its sport employees and sportspeople, to take good care of its supporters and fans, and to always have their backing for them. At the same time, the sport organization can successfully apply its strategies and, if needed, to modify them as per the conditions in the sport. That is a good approach for development of its own leadership, which is supposed to act on the highly competitive European level. Simultaneously, the sport organization will be able to monitor everything currently going on, and later to have it analyzed as well. These are situations when the surroundings and sport procedures have to be involved and included. All these activities are supposed to be sufficient in order to achieve the goals and results of the respective sport organization.

\section{REFERENCES}

Ashouri, T., Boroumand, R. M., \& Darzi, F. A. (2015). The Condition of Knowledge Management in Sport Organizations. European Online Journal of Natural and Social Sciences, 4(1), 970-976.

Byers, T., Slack, T., \& Parent, M. (2012). Key Concepts in Sport Management. London, United Kingdom: SAGE Publications. doi:10.4135/9781473914599 
Chelladurai, P. (2006). Human Resource Management in Sport and Recreation. Windsor, ON, Canada: Human Kinetics.

Covell, D., Walker, S. H., Siciliano, J., \& Hess, P. W. (2002). Managing Sports Organizations: Responsibility for Performance. Thomson South - Western.

Garland, R., Charbonneau, J., \& Macpherson, T. (2008). Measuring sport sponsorship effectiveness: links to existing behavior. Innovative Marketing, 4(1), 46-51.

Gustavson, B. (2007). The Principles of Knowledge Creation: Research Methods in the Social Sciences. Cheltenham, UK: Edvard Elgar Publishing.

Hislop, D. (2013). Knowledge Management in Organizations: A Critical Introduction. Oxford, UK: Oxford University Press.

Hoye, R., Smith, C. T. A., Nicholson, M., \& Stewart, B. (2015). Sport Management Principles and Applications. New York, USA: Routledge.

Ichijo, K., \& Nonaka, I. (2006). Knowledge creation and management: New challenges for managers. Oxford university press.

Kase, K., de Hoyos, I. U., Sanchís, C. M., \& Bretón, M. O. (2007). The proto-image of Real Madrid: implications for marketing and management. International Journal of Sports Marketing and Sponsorship, 8(3), 7-28. doi:10.1108/ijsms-08-03-2007-b004

Leonard, D. (2006). Knowledge Transfer Within Organizations. In K. Ichijo \& I. Nonaka (Eds.), Knowledge Creation and Management: New Challenges for Managers (57-68). New York, USA: Oxford University Press.

Li, M., Macintosh, W. E., Bravo, A. G. (2012). International Sport Management. Champaign, IL, USA: Human Kinetics.

Maguire, J. (2014). Social Science in Sport. Champaign, IL, USA: Human Kinetics.

Malicko, J. (2008). Modelovanje strateškog menadzmenta u sportu. Sport Scienis, 1, 12-17.

Mason, D.S. (1999). What is the sports product and who buys it? The marketing of professional sports leagues. European Journal of Marketing, 33(3/4), 402-419. doi:10.1108/03090569910253251

Masterman, G. (2009). Strategic Sport Event Management. Oxford, UK: Butterworth - Heinemann. 
McInerney, C. R., \& Koenig, M. E. D. (2011). Knowledge Management (KM) Processes in Organizations: Theoretical Foundations and Practice. USA: Morgan and Claypool Publisher.

Nicholson, M. (2007). Sport and the Media: Managing the Nexus. Oxford, UK: Elsevire, Senior Lecture in Sport Management.

Peterson, R. M., Ahamed, V. S., \& Erdogan, S. S. (2010). Processing,Switching and Communication of Knowledge. International Journal of Managing Information Technology, 2(3), 44-60. doi:10.5121/ijmit.2010.2304

Quatman, C., \& Chelladurai, P. (2007). Network Perspectives on Organizations. In International Perspectives on the Management of Sport. (61-80). Elsevier BV. doi:10.1016/b978-0-7506-8237-4.500108

Robinson, J. M. (2010). Sport Club Management. Leeds, UK: Human Kinetics.

Slack, T., \& Parent, M. M. (2006). Understending Sport Organizations: The Application of Organizational Theory. Champaign, IL, USA: Human Kinetics.

Smith, C. T. A., \& Stewart, B. (2015). Introduction to Sport Marketing. New York, USA: Routledge.

Travica, B. (1998). Information aspects of new organizational designs: Exploring the non-traditional organization. Journal of the American Society for Information Science, 49(13), 1224-1244. doi:10.1002/(sici)1097-4571(1998110)49:13<1224::aid-asi8>3.0.co;2$\mathrm{v}$

Walker, T. (2016). Sport and Twitter are a "perfect fit", according to the social media giant's global leader for sport - Alex Trickett. Sport Management, 115 (7); 24-26

Walters, G., \& Hamil, S. (2010). Ownership and Governance. In Managing Football: An international Perspective (17-36). Oxford, UK: Butterworth - Heinemann. doi:10.1016/b978-1-85617-544-9.00002-3

Shegavikj, (2016). April 9th, day of Macedonian football: On Easter day the Turkish soldiers rolled over the football (soccer) ball in Macedonia. In Utrinski Vesnik (27). Skopje, the Republic of Macedonia: Media print

Primljeno: 20.12.2017. Odobreno: 08.01.2018. 